\title{
Knowledge, Attitude, and Practice of Pediculus Capitis Prevention and Control and Their Predictors among Schoolchildren in Woreta Town, Northwest Ethiopia, 2018: A School-Based Cross-Sectional Study
}

\author{
Henok Dagne $\mathbb{D}^{1},{ }^{1}$ Awel Aba Biya, ${ }^{1}$ Amanuel Tirfie, ${ }^{1}$ Walelegn Worku Yallew ${ }^{1}$, 1 \\ Zewudu Andualem $\mathbb{D}^{1},{ }^{1}$ and Baye Dagnew $\mathbb{D}^{2}$ \\ ${ }^{1}$ Department of Environmental and Occupational Health and Safety, Institute of Public Health, College of Medicine and \\ Health Sciences, University of Gondar (UoG), P.O. Box 196, Gondar, Ethiopia \\ ${ }^{2}$ Department of Human Physiology, School of Medicine, UoG, P.O. Box 196, Gondar, Ethiopia
}

Correspondence should be addressed to Henok Dagne; enoch2313@gmail.com and Baye Dagnew; bayedagnew7@gmail.com

Received 18 May 2020; Revised 2 June 2020; Accepted 8 June 2020; Published 1 July 2020

Academic Editor: Frederick J. Kaskel

Copyright (c) 2020 Henok Dagne et al. This is an open access article distributed under the Creative Commons Attribution License, which permits unrestricted use, distribution, and reproduction in any medium, provided the original work is properly cited.

\begin{abstract}
Background. Pediculus capitis is a human head lice infestation, a major public health issue that is most prevalent in resource-limited countries globally. The current study aimed to assess the knowledge, attitude, and practice of pediculus capitis prevention and control and their predictors among schoolchildren in North West Ethiopia. Methods. About 402 randomly selected schoolchildren from three schools in Woreta town participated in the study from April to June 2018. The outcomes of this study were knowledge, attitude, and self-reported practice of schoolchildren about pediculus capitis prevention and control. We used EPI Info 7.1 and SPSS 21 software for data entry and analysis, respectively. Binary logistic regression was employed to test the association of covariates with the outcome/response variables. Variables with a $p$ value $<0.2$ during the bivariable binary logistic regression analysis were included in the multivariable binary logistic regression analysis. Variables with $p$ value $<0.05$ were declared as significantly associated with outcomes. Results. The mean age of the study participants was $10.19( \pm 1.62)$ years. About $58.8 \%, 45.8 \%$, and $78.6 \%$ of the schoolchildren had better self-reported pediculus capitis prevention knowledge, attitude, and practice, respectively. Age of children [9 to 11 years $(\mathrm{AOR}=2.24,95 \%$ C.I $(1.10,4.55)$ ) and $>12$ years $(\mathrm{AOR}=3.84$, $95 \%$ C.I $(1.56,9.46))]$, better practice $(\mathrm{AOR}=2.93$, 95\% C.I $(1.39,6.18))$, and those who were not infested $(\mathrm{AOR}=2.25,95 \%$ C.I $(1.14$, 4.44)) were predictors of knowledge regarding pediculus capitis prevention. Better practice (AOR $=4.33,95 \%$ C.I (1.69, 11.09)) and absence of infestation ( $\mathrm{AOR}=2.97,95 \%$ C.I $(1.64,5.36)$ ) were predictors of attitude of schoolchildren about pediculus capitis prevention. Number of students in a class [ 51 to 56 students per classroom, AOR $=4.61,95 \%$ C.I (1.83, 11.67$) ; 57$ to 58 students per classroom, $\mathrm{AOR}=8.18,95 \%$ C.I $(2.73,24.46)]$, less than five family size (AOR $=2.37,95 \%$ C.I $(1.24$, 4.54)), better knowledge $(\mathrm{AOR}=2.93,95 \%$ C.I $(1.32,6.50))$, desirable attitude $(\mathrm{AOR}=4.24,95 \%$ C.I $(1.60,11.23))$, and absence of infestation $(\mathrm{AOR}=3.52$, 95\% C.I $(1.22,10.15))$ were predictors of self-reported pediculus capitis prevention practice. Conclusion. The knowledge, attitude, and practice of schoolchildren regarding pediculus capitis prevention and control were not satisfactory. To bring change, intensive efforts on factors associated with the knowledge, attitude, and practice should be encouraged.
\end{abstract}

\section{Background}

Pediculus capitis is infestation by head lice that is a major public health problem globally which is most prevalent in low-income countries [1]. It is an omnipresent issue in children [2] in both schools and in the broader community [3].
Pediculus capitis can cause loss of sleep, irritation, pruritus, discomfort, secondary bacterial infections (such as impétigo and acute glomerulonephritis), and lymphadenopathy $[4,5]$. The head lice are a potential vector for disease-causing organisms such as Rickettsia prowazekii, Bartonella quintana, and Borrelia recurrentis [6-11]. The methods to reduce the 
TABLE 1: Explanatory variables of school children Woreta town, $2018(n=402)$.

\begin{tabular}{|c|c|c|c|}
\hline Variables & Categories & Frequency & Percent (\%) \\
\hline \multirow{4}{*}{ Student grade level } & Grade1 & 99 & 24.6 \\
\hline & Grade2 & 99 & 24.6 \\
\hline & Grade3 & 100 & 24.9 \\
\hline & Grade4 & 104 & 25.9 \\
\hline \multirow{2}{*}{ Sex } & Male & 186 & 46.3 \\
\hline & Female & 216 & 53.7 \\
\hline \multirow{3}{*}{ Age } & $5-8$ & 85 & 21.1 \\
\hline & $9-11$ & 230 & 57.2 \\
\hline & $>12$ & 87 & 21.6 \\
\hline \multirow{3}{*}{ Religion } & Orthodox & 291 & 72.4 \\
\hline & Muslim & 108 & 26.9 \\
\hline & Protestant & 3 & 0.7 \\
\hline \multirow{3}{*}{ Fathers education } & Illiterate & 111 & 27.6 \\
\hline & Elementary & 161 & 40 \\
\hline & $\begin{array}{l}\text { Secondary and } \\
\text { above }\end{array}$ & 130 & 32.3 \\
\hline \multirow{3}{*}{ Mothers education } & Illiterate & 171 & 42.5 \\
\hline & Elementary & 162 & 40.3 \\
\hline & $\begin{array}{l}\text { Secondary and } \\
\text { above }\end{array}$ & 69 & 17.2 \\
\hline \multirow{4}{*}{ Fathers occupation } & Private worker & 153 & 38.1 \\
\hline & $\begin{array}{l}\text { Government } \\
\text { worker }\end{array}$ & 64 & 15.9 \\
\hline & Daily labor & 42 & 10.4 \\
\hline & Others & 143 & 35.6 \\
\hline \multirow{4}{*}{ Mother's occupation } & Private worker & 62 & 15.4 \\
\hline & $\begin{array}{l}\text { Government } \\
\text { worker }\end{array}$ & 25 & 6.2 \\
\hline & Housewife & 240 & 59.7 \\
\hline & Others & 75 & 18.7 \\
\hline \multirow{2}{*}{ Family size } & $\leq 5$ & 227 & 56.4 \\
\hline & $>5$ & 175 & 45.6 \\
\hline \multirow{2}{*}{$\begin{array}{l}\text { Personal hygiene } \\
\text { control }\end{array}$} & Yes & 106 & 26.4 \\
\hline & No & 296 & 73.6 \\
\hline \multirow{2}{*}{ Water access } & Yes & 28 & 7 \\
\hline & No & 374 & 93 \\
\hline \multirow{4}{*}{$\begin{array}{l}\text { Average number of } \\
\text { students per classroom }\end{array}$} & $40-50$ & 116 & 28.9 \\
\hline & $51-56$ & 121 & 30.1 \\
\hline & $57-58$ & 89 & 22.1 \\
\hline & $59-67$ & 76 & 18.9 \\
\hline
\end{tabular}

morbidity and prevalence of pediculus capitis include strategies targeted at increasing knowledge, changing attitudes and behaviors, and improving personal hygiene practice [6]. Even though pediculus capitis is very common in Africa from earlier times until now [12-15], there are only a few studies on knowledge, attitude, and practice regarding head lice infesta-

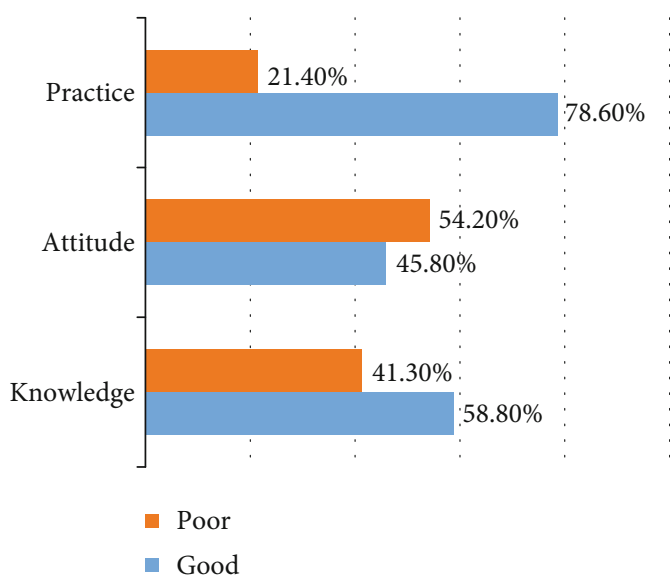

Figure 1: Knowledge, attitude, and practice towards Pediculus capitis prevention and control among schoolchildren Woreta, $2018(n=402)$

TABle 2: Correlation between knowledge, attitude, and practice towards Pediculus capitis prevention and control among schoolchildren Woreta, $2018(n=402)$.

\begin{tabular}{lcc}
\hline Variables & Correlation coefficient & $p$ value* \\
\hline Knowledge-attitude & 0.629 & $<0.001$ \\
Knowledge-practice & 0.363 & $<0.001$ \\
Attitude-practice & 0.370 & $<0.001$ \\
\hline
\end{tabular}

*Correlation significant at $p<0.01$.

tions especially in sub-Saharan Africa [16]. Above all, majority of the previous studies focused on the knowledge, attitude, and practice of parents, nurses, and teachers only [17-21]. Let alone the level of knowledge about human head lice and their control in high-income countries is restricted in resourceconstrained settings among schoolchildren [16, 19, 20, 22] and even insufficient among health professionals [23-25]. The major setbacks for ineffective control of pediculus capitis include lack of knowledge, undesirable attitude towards control and prevention of head lice, and inadequate personal hygiene practice [26-28].

Therefore, the present study was undertaken to assess the level of knowledge, attitude, practice, and their associated factors regarding pediculus capitis prevention and control among schoolchildren in Woreta town, northwest Ethiopia.

\section{Methods}

2.1. Study Design and Setting. This was a school-based crosssectional study conducted from April to June 2018 among schoolchildren in Woreta town primary schools. The town is located $589 \mathrm{~km}$ far from Addis Ababa, the capital city of Ethiopia. During the study period, there were three primary schools in the town with a total of 3239 students. The prevalence of pediculus capitis during the study period was $65.7 \%$ (95\% CI 60.01-70.3\%) [29]. 
TABLE 3: Factors associated with knowledge regarding pediculus capitis prevention and control among schoolchildren Woreta, 2018 ( $n=402)$.

\begin{tabular}{|c|c|c|c|c|c|}
\hline \multirow{2}{*}{ Variables } & \multirow{2}{*}{ Categories } & & \multirow{2}{*}{ COR $(95 \% \mathrm{CI})$} & \multirow{2}{*}{$\operatorname{AOR}(95 \% \mathrm{CI})$} \\
\hline & & Good (\%) & Poor $(\%)$ & & \\
\hline \multirow{3}{*}{ Age in years } & 5 to 8 & $37(43.5)$ & $48(56.5)$ & 1 & 1 \\
\hline & 9 to 11 & $136(59.1)$ & $94(40.9)$ & $1.88(1.14,3.10)$ & $2.24(1.10,4.55) *$ \\
\hline & $\geq 12$ & $63(72.4)$ & $24(27.6)$ & $3.41(1.80,6.43)$ & $3.84(1.56,9.46) * *$ \\
\hline \multirow{3}{*}{ Fathers education } & Illiterate & $53(47.7)$ & $58(52.3)$ & 1 & 1 \\
\hline & Elementary & $93(57.8)$ & $68(42.2)$ & $1.50(0.92,2.43)$ & $1.18(0.55,2.56)$ \\
\hline & Secondary and above & $90(69.2)$ & $40(30.8)$ & $2.46(1.45,4.17)$ & $1.73(0.65,4.64)$ \\
\hline \multirow{3}{*}{ Mothers education } & Illiterate & $88(51.5)$ & $83(48.5)$ & 1 & 1 \\
\hline & Elementary & $99(61.1)$ & $63(38.9)$ & $1.48(0.96,2.29)$ & $0.80(0.37,1.72)$ \\
\hline & Secondary and above & $49(71)$ & $20(29)$ & $2.31(1.27,4.21)$ & $0.73(0.24,2.22)$ \\
\hline \multirow{4}{*}{ Number of students per class } & $40-50$ & $78(67.2)$ & $38(32.8)$ & $2.03(1.12,3.67)$ & $1.77(0.76,4.16)$ \\
\hline & $51-56$ & $62(51.2)$ & $59(48.8)$ & $1.05(0.59,1.86)$ & $0.68(0.29,1.61)$ \\
\hline & $57-58$ & $58(65.2)$ & $31(34.8)$ & $1.87(1.00,3.50)$ & $0.96(0.38,2.45)$ \\
\hline & $59-67$ & $38(50)$ & $38(50)$ & 1 & 1 \\
\hline \multirow{2}{*}{ Family size } & $\leq 5$ & $146(64.3)$ & $81(35.7)$ & $1.70(1.14,2.55)$ & $1.00(0.56,1.80)$ \\
\hline & $>5$ & $90(51.4)$ & $85(48.6)$ & 1 & 1 \\
\hline \multirow{2}{*}{ Water accessibility } & Yes & $13(46.4)$ & $15(53.6)$ & $0.59(0.27,1.27)$ & $0.75(0.26,2.16)$ \\
\hline & No & $223(59.6)$ & $151(40.4)$ & 1 & 1 \\
\hline \multirow{2}{*}{ Attitude towards pediculus capitis prevention } & Poor & $66(30.3)$ & $152(69.7)$ & 1 & 1 \\
\hline & Good & $170(92.4)$ & $14(7.6)$ & $27.96(15.09,51.82)$ & $16.95(8.74,32.88) * * *$ \\
\hline \multirow{2}{*}{ Practice towards pediculus capitis prevention } & Poor & $21(24.4)$ & $65(75.6)$ & 1 & 1 \\
\hline & Good & $215(68)$ & $101(32)$ & $6.59(3.82,11.37)$ & $2.93(1.39,6.18) * *$ \\
\hline \multirow{2}{*}{ Pediculus capitis infestation } & Yes & $116(84.1)$ & $22(15.9)$ & 1 & 1 \\
\hline & No & $120(45.5)$ & $144(54.5)$ & $6.33(3.78,10.6)$ & $2.25(1.14,4.44) *$ \\
\hline
\end{tabular}

Significant at $* p \leq 0.05, * * p \leq 0.01, * * * p \leq 0.001$, Hosmer-Lemeshow goodness-of-fit $(p=0.196) 1$ reference.

2.2. Sample Size Calculation and Sampling Procedure. For the present study, the sample size was determined using a single population proportion formula [30]. With the following assumptions: $p=50$ percent to allow maximum variation (as there was no previous country analysis on the ratio of knowledge, attitude, and practice to pediculus capitis prevention and control), 95 percent confidence level, $z=$ standard normal tabulated value, and $\alpha=$ level of significance and margin of error $(d)=0.05$;

$$
n=\frac{\left(z_{\alpha / 2}\right)^{2} p(1-p)}{d^{2}}=\frac{(1.96)^{2} 0.5(1-0.5)}{0.05^{2}}=384
$$

The final total sample size was 402, after adding the estimated nonresponse rate of 5 percent. Study participants were chosen using a simple random sampling technique and distributed in proportion to the three schools, based on the number of students in each school.

2.3. Data Collection Tool and Quality Control Procedures. A pretested, semistructured questionnaire was used that included socio-demographic variables, knowledge, attitude, and practice items relevant to infestation with pediculus capitis. Two Environmental Health Bachelor's degree students conducted an interview and observation after receiving training on the data collection method, techniques, study intent, and ethical considerations.

Detailed explanation and reliability of the method for data collection based on the pretest results are discussed elsewhere [29].

\subsection{Variable Measurement}

2.4.1. Pediculusis. A child with at least one head louse by wet combing is assumed to be infested with pediculus capitis [14].

2.4.2. Schoolchildren. In the current report, children attending classes from grades 1 to 4 were considered schoolchildren [29].

2.4.3. Knowledge. Knowledge was measured by 10 yes/no category knowledge items.

Students who scored mean of knowledge questions and above were deemed to have good knowledge [29].

2.4.4. Attitude. Attitude was assessed by 8 Likert-scale attitude questions (1-strongly disagree with 5-strongly agree). Children who scored mean and above questions about the attitude were known as having a good attitude [29]. 
TABLE 4: Factors associated with attitude regarding pediculus capitis prevention among schoolchildren Woreta, $2018(n=402)$.

\begin{tabular}{|c|c|c|c|c|c|}
\hline \multirow{2}{*}{ Variables } & \multirow{2}{*}{ Categories } & \multicolumn{2}{|c|}{ Attitude } & \multirow{2}{*}{ COR $(95 \% \mathrm{CI})$} & \multirow{2}{*}{ AOR $(95 \% \mathrm{CI})$} \\
\hline & & Good (\%) & Poor & & \\
\hline \multirow{3}{*}{ Age in years } & 5 to 8 & $30(35.3)$ & $55(64.7)$ & 1 & 1 \\
\hline & 9 to 11 & $105(45.7)$ & $125(54.3)$ & $1.54(0.92,2.58)$ & $1.18(0.56,2.46)$ \\
\hline & $\geq 12$ & $49(56.3)$ & $38(43.7)$ & $2.36(1.28,4.37)$ & $1.47(0.61,3.57)$ \\
\hline \multirow{3}{*}{ Fathers education } & Illiterate & $35(31.5)$ & $76(68.5)$ & 1 & 1 \\
\hline & Elementary & $76(47.2)$ & $85(52.8)$ & $1.94(1.17,3.22)$ & $1.87(0.84,4.17)$ \\
\hline & $\geq$ secondary & $73(56.2)$ & $57(43.8)$ & $2.78(1.64,4.71)$ & $1.65(0.61,4.44)$ \\
\hline \multirow{3}{*}{ Mothers education } & Illiterate & $64(37.4)$ & $107(62.6)$ & 1 & 1 \\
\hline & Elementary & $78(48.1)$ & $84(51.9)$ & $1.55(1.00,2.40)$ & $0.72(0.34,1.53)$ \\
\hline & $\geq$ secondary & $42(60.9)$ & $27(39.1)$ & $2.6(1.46,4.62)$ & $0.90(0.38,2.20)$ \\
\hline \multirow{4}{*}{ Number of students per class } & $40-50$ & $56(48.3)$ & $60(51.7)$ & $1.49(0.82,2.68)$ & $0.78(0.34,1.81)$ \\
\hline & $51-56$ & $51(42.1)$ & $70(57.9)$ & $1.18(0.66,2.12)$ & $0.92(0.38,2.20)$ \\
\hline & $57-58$ & $48(53.9)$ & $41(46.1)$ & $1.90(1.02,3.54)$ & $0.96(0.39,2.40)$ \\
\hline & $59-67$ & $29(38.2)$ & $47(61.8)$ & 1 & 1 \\
\hline \multirow{2}{*}{ Family size } & $\leq 5$ & $119(52.4)$ & $108(47.6)$ & $1.86(1.25,2.79)$ & $1.19(0.67,2.12)$ \\
\hline & $>5$ & $65(37.1)$ & $110(62.9)$ & 1 & 1 \\
\hline \multirow{2}{*}{ Knowledge towards pediculus capitis prevention } & Poor & $14(8.4)$ & $152(91.6)$ & 1 & 1 \\
\hline & Good & $170(72)$ & $66(28)$ & $27.96(15.09,51.82)$ & $17.32(8.90,33.72) * * *$ \\
\hline \multirow{2}{*}{ Practice towards pediculus capitis prevention } & Poor & $9(10.5)$ & $77(89.5)$ & 1 & 1 \\
\hline & Good & $175(55.4)$ & $141(44.6)$ & $10.62(5.14,21.93)$ & $4.33(1.69,11.09) * *$ \\
\hline \multirow{2}{*}{ pediculus capitis infestation } & Yes & $81(30.7)$ & $183(69.3)$ & 1 & 1 \\
\hline & No & $103(74.6)$ & $35(25.4)$ & $6.65(4.18,10.58)$ & $2.97(1.64,5.36) * * *$ \\
\hline
\end{tabular}

Significant at $* p \leq 0.05, * * p \leq 0.01, * * * p \leq 0.001$, Hosmer-Lemeshow goodness-of-fit $(p=0.134)$. COR: crude odds ratio; AOR: adjusted odds ratio; CI: confidence interval.

2.4.5. Practice. Children were asked five specific questions regarding the prevention behavior of pediculus capitis. Those children who scored mean and above of the questions were considered good practice [29].

2.5. Data Analysis. Completeness and consistency of the data were reviewed regularly. Epi info version 7.1 was used for data entry and analysis was performed using SPSS version 21 . We calculated the number, mean, and standard deviation to show the descriptive results.

Bivariable binary logistic regression was first tested, and in the final model, we used multivariable binary logistic regression to test variables with a $p$ value $<0.2$ in bivariable analysis for significant association. Variables with a $p$ value $<0.05$ were declared as being significantly associated with dependent variables (i.e., knowledge, attitude, and practice) in the multivariable binary logistic regression analysis.

Crude and adjusted odds ratios and 95\% confidence intervals were calculated. Model fitness was tested using Hosmer and Lemeshow good-ness of fit at $p>0.05$.

2.6. Patient and Public Participation. The current research did not include patients or the public but included students with and withoutpediculus capitis infestation.

\section{Results}

3.1. Socio-Demographic Characteristics. Four hundred and two students were included in the current study. Above half (53.7\%) of the study participants were females. The study participants' mean age was $10.19( \pm 1.62)$ years. Almost all (93\%) of the students attend in schools with no water access (Table 1).

From the total participants, $78.6 \%$ had good self-reported practice, $58.8 \%$ had good knowledge, and $45.8 \%$ had desirable attitude (Figure 1).

3.2. Correlation between Knowledge, Attitude, and Practice. The correlation between knowledge, attitude, and practice was assessed using the rank correlation coefficient of Spearman and represented using $0-0.25=$ poor, $0.25-0.5=$ average, $0.5-0.75=$ good, and above $0.75=$ excellent correlations based on criteria developed for the study of statistical power for behavioral sciences [31]. There was a significant correlation among knowledge, attitude and practice (Table 2).

3.3. Factors Associated with Knowledge regarding pediculus capitis Prevention. Age of child, paternal and maternal education, number of students per class, family size, water accessibility, attitude of students towards pediculus capitis prevention, practice towards pediculus capitis prevention, 
TABLE 5: Factors associated with pediculus capitis prevention practice among schoolchildren Woreta, $2018(n=402)$.

\begin{tabular}{|c|c|c|c|c|c|}
\hline \multirow{2}{*}{ Variables } & \multirow{2}{*}{ Categories } & \multicolumn{2}{|c|}{ Practice } & \multirow{2}{*}{ COR $(95 \% \mathrm{CI})$} & \multirow{2}{*}{$\operatorname{AOR}(95 \% \mathrm{CI})$} \\
\hline & & Good (\%) & Poor $(\%)$ & & \\
\hline \multirow{4}{*}{ Grade level } & Grade 1 & $76(76.8)$ & $23(23.2)$ & 1 & 1 \\
\hline & Grade 2 & $66(66.7)$ & $33(33.3)$ & $0.61(0.32,1.13)$ & $0.32(0.13,0.76)$ \\
\hline & Grade 3 & $79(79)$ & $21(21)$ & $1.14(0.58,2.23)$ & $0.62(0.25,1.52)$ \\
\hline & Grade 4 & $95(91.3)$ & $9(8.7)$ & $3.19(1.40,7.31)$ & $0.57(0.18,1.80)$ \\
\hline \multirow{3}{*}{ Fathers education } & Illiterate & $72(64.9)$ & $39(35.1)$ & 1 & 1 \\
\hline & Elementary & $125(77.6)$ & $36(22.4)$ & $1.88(1.10,3.22)$ & $0.92(0.43,1.98)$ \\
\hline & Secondary and above & $119(91.5)$ & $11(8.5)$ & $5.86(2.82,12.16)$ & $1.46(0.47,4.50)$ \\
\hline \multirow{3}{*}{ Mothers education } & Illiterate & $113(66.1)$ & $58(33.9)$ & 1 & 1 \\
\hline & Elementary & $137(84.6)$ & $25(15.4)$ & $2.81(1.65,4.78)$ & $1.29(0.56,2.92)$ \\
\hline & $\geq$ secondary & $66(95.7)$ & $3(4.3)$ & $11.29(3.40,37.47)$ & $5.36(0.98,29.36)$ \\
\hline \multirow{4}{*}{ Number of students per class } & $40-50$ & $92(79.3)$ & $24(20.7)$ & $2.94(1.55,5.57)$ & $2.20(0.90,5.38)$ \\
\hline & $51-56$ & $99(81.8)$ & $22(18.2)$ & $3.45(1.81,6.60)$ & $4.61(1.83,11.67) * * *$ \\
\hline & $57-58$ & $82(92.1)$ & $7(7.9)$ & $8.99(3.67,22.01)$ & $8.18(2.73,24.46) * * *$ \\
\hline & $59-67$ & $43(36.6)$ & $33(43.4)$ & 1 & 1 \\
\hline \multirow{2}{*}{ Family size } & $\leq 5$ & $197(86.8)$ & $30(13.2)$ & $3.09(1.88,5.09)$ & $2.37(1.24,4.54) * *$ \\
\hline & $>5$ & $119(68)$ & $56(32)$ & 1 & 1 \\
\hline \multirow{2}{*}{ Knowledge towards pediculus capitis prevention } & Poor & $101(60.8)$ & $65(39.2)$ & 1 & 1 \\
\hline & Good & $215(91.1)$ & $21(8.9)$ & $6.56(3.82,11.37)$ & $2.93(1.32,6.50) * *$ \\
\hline \multirow{2}{*}{ Attitude towards pediculus capitis prevention } & Poor & $141(64.7)$ & $77(35.3)$ & 1 & 1 \\
\hline & Good & $175(95.1)$ & $9(4.9)$ & $10.62(5.14,21.93)$ & $4.24(1.60,11.23) * *$ \\
\hline \multirow{2}{*}{ Pediculus capitis infestation } & Yes & $184(69.7)$ & $80(30.3)$ & 1 & 1 \\
\hline & No & $132(95.7)$ & $6(4.3)$ & $9.56(4.05,22.57)$ & $3.52(1.22,10.15) *$ \\
\hline
\end{tabular}

Significant at $* p \leq 0.05, * * p \leq 0.01, * * * p \leq 0.001$, Hosmer-Lemeshow goodness-of-fit $(p=0.478) 1$ reference.

and previous history of pediculus capitis infestation were variables candidate for the multivariable binary logistic regression analysis as they have $p$ value less than 0.2 . Only age, attitude towards pediculus capitis prevention, practice towards pediculus capitis prevention, and pediculus capitis infestation were associated with knowledge regarding pediculus capitis prevention during the multivariable binary logistic regression analysis. Children aged 9 to 11 years had 2.24 times $[\mathrm{AOR}=2.24,95 \%$ C.I $(1.10,4.55)]$, and those aged $\geq 12$ years had 3.84 times $[\mathrm{AOR}=3.84$, 95\% C.I (1.56, 9.46)] better pediculus capitis prevention knowledge than those aged 5 to 8 years. Schoolchildren with good pediculus capitis prevention practice had 2.93 times better knowledge as compared to those with poor practice [AOR $=2.93,95 \%$ C.I $(1.39,6.18)]$. Study participants with previous history of pediculus capitis had twice better preventive knowledge than those with no history of infestation $[A O R=2.25,95 \%$ C.I $(1.14,4.44)$ ] (Table 3$)$.

Students' knowledge towards pediculus capitis prevention, practice towards pediculus capitis prevention, and previous history of pediculus capitis infestation were factors associated with attitude about pediculus capitis prevention during the multivariable logistic regression (Table 4).

Grade level, paternal and maternal educational status, number of students per classroom, family size, knowledge and attitude towards pediculus capitis prevention, and history of infestation were factors eligible $(p<0.2)$ for multivariable analysis in the final model. The only number of students per classroom, family size, knowledge, attitude, and history of infestation was associated with pediculus capitis prevention practice during the multivariable analysis. Class size was associated with practice regarding pediculus capitis prevention. Students attending in larger size class had better prevention practice compared with those in smaller size classes. Students from lower family size had better pediculus capitis prevention practice [AOR: 2.37, 95\% C.I $(1.24,4.54)]$. Children with good knowledge had 2.93 times better practice than those with poor knowledge [AOR: 2.93, 95\% C.I $(1.32,6.50)]$. Study participants with desirable attitudes had 4.24 times better prevention practice than those with undesirable attitudes [AOR: 4.24 , 95\% C.I $(1.60,11.23)]$. Children with previous history of infestation by pediculus capitis had better prevention practice [AOR: 3.52, 95\% C.I (1.22, 10.15)] (Table 5).

\section{Discussion}

In this study, we evaluated the level of knowledge, attitude, and practice regarding pediculus capitis prevention and control among schoolchildren in Woreta town. This study is a 
part of a project on a school health assessment program, and detailed information about prevalence and risk factors of pediculus capitis is published elsewhere [29]. In the current manuscript, we have assessed the knowledge, attitude, and practice regarding pediculus capitis prevention and control and their associated factors. Knowledge was a significant predictor of infestation status in previous studies [19, 29, 32]. This may be due to the lack of knowledge that can result in insufficient capacity to handle lice infestation. Several interventional studies concentrated on health education intervention to improve knowledge of school teachers, guardians, and students [33, 34]. Deficiencies in knowledge may indicate inabilities to manage infestation. In the current analysis, the positive associations between knowledge-attitude, knowledge-practice, and attitude-practice notify the relationship among knowledge, attitude, and practice about pediculus capitis prevention. Sufficient knowledge will result in a positive attitude leading to better practice. This is in line with previous studies $[35,36]$. Students with higher age, better attitude and practice, and those with no previous history of infestation had better-adjusted odds of knowledge regarding pediculus capitis prevention. Students with higher age were less likely to be infested [5]. In the current study, students with higher age were found to have better infestation prevention and control knowledge. This is in line with earlier studies [37].

Family size less than five, better knowledge and desirable attitude, and not being infested by pediculus capitis were among factors associated with practice regarding pediculus capitis prevention among schoolchildren. Previous research showed that children from lower socioeconomic classes and those with lower-educated parents were more frequently infested [38-43]. Greater family size was identified as a determinant for pediculus capitis in several earlier studies [44-46].

In the current study, students with better knowledge and desirable attitude more likely reported better pediculus capitis prevention and control practice. Health practice is defined by the knowledge and attitude of an individual or the public [37].

This research was, ultimately, not without limitations. No evaluation was made of the knowledge, attitude, and practice of school teachers and parents. The scarcity of previous studies on knowledge, attitude, practice, and associated factors among children made comparison of results difficult. An additional limitation of this study has been the inherent weakness of cross-sectional research design in determining cause-effect relationship, recall and social desirability bias, and poor generalizability as the analysis is performed only at a specific city.

\section{Conclusion}

Head lice infestation is a major public health concern and the national and regional health authorities need to advocate awareness-raising programs that target mothers and prepare knowledge, attitude, and practice improvement strategies.

\section{Abbreviations}

AOR: $\quad$ Adjusted odds ratio

COR: Crude odds ratio
CI: $\quad$ Confidence interval

EPI Info: Epidemiological information

SPSS: Statistical Package for Social Sciences.

\section{Data Availability}

The datasets available from the corresponding authors upon reasonable request.

\section{Ethical Approval}

Ethical approval was secured from the department of Environmental and Occupational Health and Safety Ethical committee. Written consent was obtained from parents and school directors. Accent was received from study participants. Any possible identifiers were avoided to ensure confidentiality. Health education about pediculus capitis prevention and control, transmission routes, and personal hygiene was delivered for school teachers, students, and directors after completion of data collection. School directors were advised to regularly check the personal hygiene of students. Students with pediculus capitis were advised for visiting nearby clinics.

\section{Conflicts of Interest}

None of the authors declared competing interest.

\section{Authors' Contributions}

HD designed and supervised the study, analysed the data, and wrote the draft manuscript. WWY participated in the design of the study, revised the draft manuscript, and critically revised the draft manuscript for the methodological and intellectual soundness. AT, AAB, ZA, and BD involved from proposal writing, participated in data collection, until the manuscript writing phase. The final manuscript was read and accepted by all contributors.

\section{Acknowledgments}

The authors are grateful to the University of Gondar, data collectors, supervisors, Woreta education office, and study participants for their invaluable support and cooperation to conduct the research.

\section{References}

[1] D. Pilger, J. Heukelbach, A. Khakban, F. A. Oliveira, G. Fengler, and H. Feldmeier, "Household-wide ivermectin treatment for head lice in an impoverished community: randomized observer-blinded controlled trial," Bulletin of the World Health Organization, vol. 88, no. 2, pp. 90-96, 2010.

[2] D. L. Bonilla, L. A. Durden, M. E. Eremeeva, and G. A. Dasch, "The biology and taxonomy of head and body lice-implications for louse-borne disease prevention," PLoS Pathogens, vol. 9, no. 11, article e1003724, 2013.

[3] P. Magalhães, E. V. Figueiredo, and D. P. Capingana, "Head lice among primary school children in Viana, Angola: prevalence and relevant Teachers\&rsquo; knowledge," Human Parasitic Diseases, vol. 3, pp. 11-18, 2011. 
[4] A. Doroodgar, F. Sadr, M. Doroodgar, M. Doroodgar, and M. Sayyah, "Examining the prevalence rate of_Pediculus capitis_ infestation according to sex and social factors in primary school children," Asian Pacific journal of Tropical Disease, vol. 4, no. 1, pp. 25-29, 2014.

[5] A. Vahabi, K. Shemshad, M. Sayyadi et al., "Prevalence and risk factors of Pediculus (humanus) capitis (Anoplura: Pediculidae), in primary schools in Sanandaj City, Kurdistan Province, Iran," Tropical Biomedicine, vol. 29, no. 2, pp. 207-211, 2012.

[6] M. Yingklang, C. Sengthong, O. Haonon et al., "Effect of a health education program on reduction of pediculosis in school girls at Amphoe Muang, Khon Kaen Province, Thailand," PLoS One, vol. 13, no. 6, article e0198599, 2018.

[7] N. Amanzougaghene, F. Fenollar, A. K. Sangaré et al., "Detection of bacterial pathogens including potential new species in human head lice from Mali," PLoS One, vol. 12, no. 9, article e0184621, 2017.

[8] N. Amanzougaghene, J. Akiana, G. Mongo Ndombe et al., "Head lice of pygmies reveal the presence of relapsing fever Borreliae in the Republic of Congo," PLoS Neglected Tropical Diseases, vol. 10, no. 12, article e0005142, 2016.

[9] A. K. Sangaré, C. Socolovschi, M.-M. Olive et al., "Detection of Bartonella quintana in African body and head lice," The American Journal of Tropical Medicine and Hygiene, vol. 91, no. 2, pp. 294-301, 2014.

[10] N. Ulutasdemir, F. Eroglu, M. Tanrıverdi, E. I. Dagli, and I. S. Koltas, "The epidemic typhus and trench fever are risk for public health due to increased migration in southeast of Turkey," Acta Tropica, vol. 178, pp. 115-118, 2018.

[11] M. Moshki, F. Zamani-Alavijeh, and M. Mojadam, "Correction: efficacy of peer education for adopting preventive behaviors against head lice infestation in female elementary school students: a randomised controlled trial," PLoS One, vol. 14, no. 2, article e0212625, 2019.

[12] D. Awahmukalah, J. Dinga, and J. N. Nchako, "Pediculosis among urban and rural school children in Kumba, Meme division, south-west Cameroon," Parassitologia, vol. 30, no. 2-3, pp. 249-256, 1988.

[13] E. Ebomoyi, "Pediculosis capitis among primary schoolchildren in urban and rural areas of Kwara State, Nigeria," Journal of School Health, vol. 58, no. 3, pp. 101-103, 1988.

[14] R. Speare, J. Govere, and D. Durrheim, "The prevalence of pediculosis in rural South African schoolchildren: research in action," South African Journal of Science, vol. 99, no. 1, pp. 21-23, 2003.

[15] T. A. Abd El Raheem, N. A. El Sherbiny, A. Elgameel, G. A. El-Sayed, N. Moustafa, and S. Shahen, "Epidemiological comparative study of pediculosis capitis among primary school children in Fayoum and Minofiya governorates, Egypt," Journal of Community Health, vol. 40, no. 2, pp. 222-226, 2015.

[16] J. Heukelbach and U. S. Ugbomoiko, "Knowledge, attitudes and practices regarding head lice infestations in rural Nigeria," The Journal of Infection in Developing Countries, vol. 5, no. 9, pp. 652-657, 2011.

[17] G. M. Kirchofer, J. H. Price, and S. K. Telljohann, "Primary grade teachers' knowledge and perceptions of head lice," Journal of School Health, vol. 71, no. 9, pp. 448-452, 2001.

[18] J. H. Price, C. N. Burkhart, C. G. Burkhart, and R. Islam, "School nurses' perceptions of and experiences with head lice," Journal of School Health, vol. 69, no. 4, pp. 153-158, 1999.
[19] E. Sidoti, F. Bonura, G. Paolini, and G. Tringali, "A survey on knowledge and perceptions regarding head lice on a sample of teachers and students in primary schools of north and south of Italy," Journal of Preventive Medicine and Hygiene, vol. 50, no. 3, 2009.

[20] M. Counahan, R. M. Andrews, H. Weld, H. Walsh, and R. Speare, "What parents in Australia know and do about head lice," Rural and Remote Health, vol. 7, article 687, p. 3, 2007.

[21] A. Doulgeraki and M. Valari, "Parental attitudes towards head lice infestation in Greece," International Journal of Dermatology, vol. 50, no. 6, pp. 689-692, 2011.

[22] J. Parison and D. V. Canyon, Head Lice and the Impact of Knowledge, Attitudes and Practices-a Social Science Overview, UNI-MED, 2010.

[23] K. Mumcuoglu, M. Mumcuoglu, M. Danilevich, and L. Gilead, "Knowledge and practices of health professionals regarding head lice," in Management and control of head lice infestations, pp. 111-114, UNI-MED Verlag AG, Bremen, 2010.

[24] B. Olowokure, H. Jenkinson, M. Beaumont, and H. Duggal, "The knowledge of healthcare professionals with regard to the treatment and prevention of head lice," International Journal of Environmental Health Research, vol. 13, no. 1, pp. 11-15, 2003.

[25] Z. Philips, D. Whynes, S. Parnham, R. Slack, and S. Earwicker, "The role of community pharmacists in prescribing medication for the treatment of head lice," Journal of Public Health, vol. 23, no. 2, pp. 114-120, 2001.

[26] Z. G. Shirvani and M. S. Ardestani, "Evaluation of a health education program for head lice infestation in female primary school students in Chabahar City, Iran," Archives of Iranian Medicine, vol. 16, no. 1, p. 42, 2013.

[27] K. Y. Mumcuoglu, L. Gilead, and A. Ingber, "New insights in pediculosis and scabies," Expert Review of Dermatology, vol. 4, no. 3, pp. 285-302, 2014.

[28] R. Pourbaba, M. Moshkbide Haghighi, and P. R. Habibi, "A survey of prevalence of pediculosis among primary school students of Guilan Province in the school year of 2002-3," Journal of Guilan University of Medical Sciences, vol. 13, no. 52, pp. 1524, 2005.

[29] H. Dagne, A. A. Biya, A. Tirfie, W. W. Yallew, and B. Dagnew, "Prevalence of pediculosis capitis and associated factors among schoolchildren in Woreta town, northwest Ethiopia," BMC Research Notes, vol. 12, no. 1, p. 465, 2019.

[30] W. N. Arifin, "Introduction to sample size calculation," Education in Medicine Journal, vol. 5, no. 2, 2013.

[31] J. Cohen, The T Test for Means. Statistical Power Analysis for the Behavioural Sciences, Lawrence Erlbaum Associates, Hillsdale, NJ, 1988.

[32] H. Kassiri and E. Esteghali, "Prevalence rate and risk factors of pediculus capitis among primary school children in Iran," Archives of Pediatric Infectious Diseases, vol. 4, no. 1, 2015.

[33] B. Norsa Adah, B. Rusli, I. Aini, and L. Naing, "Is health education necessary to control head lice infestation in primary school children?," International Medical Journal-Tokyo, vol. 13, no. 1, p. 19, 2006.

[34] I. Zareban, M. Abbaszadeh, M. Moodi, H. Mehrjoufard, and H. Ghaffari, Evaluating a Health-Education Program in Order to Reduce Infection to Pediculus Humanus Capitis among Female Elementary Students, JOURNAL OF BIRJAND UNIVERSITY OF MEDICAL SCIENCES, Scientific information database, 2006. 
[35] N. ul Haq, M. A. Hassali, A. A. Shafie et al., "A cross-sectional assessment of knowledge, attitude and practice among Hepatitis-B patients in Quetta, Pakistan," BMC Public Health, vol. 13, no. 1, article 448, 2013.

[36] A. Singh and B. Purohit, "Knowledge, Attitude and Practice towards Infection Control Measures and it's Correlation among Dental Students in Bhopal city, Central India," International Journal of Infection Control, vol. 7, no. 1, 2011.

[37] L. Amelia, C. Anwar, and W. Wardiansah, "Association of sociodemographic, knowledge, attitude and practice with pediculosis capitis," Bioscientia Medicina: Journal of Biomedicine and Translational Research, vol. 3, no. 1, pp. 51-63, 2019.

[38] A. M. Khamaiseh, "Head lice among governmental primary school students in southern Jordan: prevalence and risk factors," Journal of Global Infectious Diseases, vol. 10, no. 1, pp. 11-15, 2018.

[39] M. Al Bashtawy and F. Hasna, Pediculosis capitis among primary-school children in Mafraq Governorate, Eastern Mediterranean Health JournalLa Revue de Santé de la Méditerranée orientale, Jordan, 2012.

[40] M. Davarpanah, D. Mehrabani, F. Khademolhosseini, A. Mokhtari, H. Bakhtiari, and R. Neirami, "The prevalence of Pediculus capitis among school children in Fars Province, Southern Iran," Iranian Journal of Parasitology, vol. 4, pp. 48-53, 2009.

[41] M. Gulgun, E. Balci, A. Karaoglu, O. Babacan, and T. Türker, "Pediculosis capitis: prevalence and its associated factors in primary Schoolchildren living in rural and urban areas in Kaiseri, Turkey," Central European Journal of Public Health, vol. 21, no. 2, pp. 104-108, 2013.

[42] A. Buczek, D. Markowska-Gosik, D. Widomska, and I. M. Kawa, "Pediculosis capitis among schoolchildren in urban and rural areas of eastern Poland," European Journal of Epidemiology, vol. 19, no. 5, pp. 491-495, 2004.

[43] S. Willems, H. Lapeere, N. Haedens, I. Pasteels, J.-M. Naeyaert, and J. De Maeseneer, "The importance of socio-economic status and individual characteristics on the prevalence of head lice in schoolchildren," European Journal of Dermatology, vol. 15, no. 5, pp. 387-392, 2005.

[44] H. Lesshafft, A. Baier, H. Guerra, A. Terashima, and H. Feldmeier, "Prevalence and risk factors associated with pediculosis capitis in an impoverished urban community in Lima, Peru," Journal of Global Infectious Diseases, vol. 5, no. 4, pp. 138-143, 2013.

[45] R. B. Nordin, W. A. Che, N. A. Ibrahim, and L. Naing, "Prevalence and associated factors of head lice infestation among primary schoolchildren in Kelantan, Malaysia," Southeast Asian Journal of Tropical Medicine and Public Health, vol. 37, no. 3, p. 536, 2006.

[46] V. Soultana, P. Euthumia, M. Antonios, and R. S. Angeliki, "Prevalence of pediculosis capitis among schoolchildren in Greece and risk factors: a questionnaire survey," Pediatric Dermatology, vol. 26, no. 6, pp. 701-705, 2009. 